\title{
Phenotypic and Genetic Diversity of Xanthomonas perforans Populations from Tomato in North Carolina
}

\author{
Pragya Adhikari, ${ }^{1}$ Tika B. Adhikari,, 2, Sujan Timilsina, ${ }^{3}$ Inga Meadows, ${ }^{2}$ \\ Jeffrey B. Jones, ${ }^{3}$ Dilip R. Panthee,${ }^{1}$ and Frank J. Louws ${ }^{1,2, \dagger}$ \\ ${ }^{1}$ Department of Horticultural Science, North Carolina State University, Raleigh, NC 27695 \\ 2 Department of Entomology and Plant Pathology, North Carolina State University, Raleigh, NC 27695 \\ ${ }^{3}$ Department of Plant Pathology, University of Florida, Gainesville, FL 32611 \\ Accepted for publication 28 April 2019.
}

\begin{abstract}
Bacterial spot caused by Xanthomonas spp. is one of the most devastating diseases of tomato in North Carolina (NC). In total, 290 strains of Xanthomonas spp. from tomato in NC collected over 2 years (2015 and 2016) were analyzed for phenotypic and genetic diversity. In vitro copper and streptomycin sensitivity assays revealed that $>95 \%$ $(n=290)$ of the strains were copper tolerant in both years, whereas $25 \%(n=127)$ and $46 \%(n=163)$ were streptomycin tolerant in 2016 and 2015, respectively. Using BOX repetitive element PCR assay, fingerprint patterns showed four haplotypes $(\mathrm{H} 1, \mathrm{H} 2, \mathrm{H} 3$, and $\mathrm{H} 4)$ among the strains analyzed. The multiplex real-time quantitative PCR on a subset of representative strains $(n=45)$ targeting the highly conserved $h r c N$ gene identified Xanthomonas strains from tomato in NC that belonged to $X$. perforans. Race profiling of the representative strains $(n=45)$ on tomato and pepper differentials confirmed that $\sim 9$ and $91 \%$ of strains are tomato races $\mathrm{T} 3$ and $\mathrm{T} 4$, respectively.
\end{abstract}

ABSTRACT

Additionally, PCR assays and sequence alignments confirmed that the copL, copA, copB (copLAB copper tolerance gene cluster), and $a v r X v 4$ genes are present in the strains analyzed. Phylogenetic and comparative sequence analyses of six genomic regions (elongation factor G [fusA], glyceraldehyde-3-phosphate dehydrogenase A [gapA], citrate synthase [gltA], gyrase subunit B [ $g y r B]$, ABC transporter sugar permease $[l a c F]$, and GTP binding protein $[$ lepA]) suggested that 13 and $74 \%$ of $X$. perforans strains from NC were genetically similar to races T3 and T4 from Florida, respectively. Our results provide insights that bacterial spot management practices in tomato should focus on deploying resistance genes to combat emerging pathogenic races of $X$. perforans and overcome the challenges currently posed by intense use of copper-based bactericides.

Keyword: population biology
Bacterial spot (Xanthomonas spp.) is an economically important disease of fresh market tomato (Solananum lycopersicum L.) in North Carolina (NC) and several other states (Louws et al. 2001). At least four species within the genus Xanthomonas (X. euvesicatoria, $X$. gardneri, $X$. perforans, and $X$. vesicatoria) have been reported to cause bacterial spot in tomato (Jones et al. 2004). X. euvesicatoria, $X$. perforans, and $X$. vesicatoria are favored by warm temperatures $\left(25\right.$ to $\left.30^{\circ} \mathrm{C}\right)$, whereas $X$. gardneri strains prefer cooler temperatures $\left(<20^{\circ} \mathrm{C}\right)$ (Araújo et al. 2011). In addition, four pathogenic races (T1, T2, T3, and T4) of Xanthomonas spp. associated with differential hosts have been reported (Jones et al. 2004). The race T1 includes strains with avrRxv effector eliciting a hypersensitive response (HR) in a tomato differential HI 7998; all T1 strains identified so far are X. euvesicatoria (Scott et al. 1996; Whalen et al 1993). T2 race differed from race $\mathrm{T} 1$ by the deletion of the 680-bp region of $a v r R x v$ (Whalen et al. 1993) and belongs to X. vesicatoria (Stall et al. 2009). Tomato genotype showing HR response to T2 strains has not been reported yet. The $\mathrm{T} 3$ race includes strains containing avrXv3

†Corresponding authors: T. B. Adhikari; tbadhika@ncsu.edu,

and F. J. Louws; frank_louws@ncsu.edu

Current address of P. Adhikari: Department of Crop Science, University of Illinois at Urbana-Champaign, Urbana, IL 61801.

Funding: This research was supported by National Science Foundation grant IOS1546625 (to D. R. Panthee). P. Adhikari was a graduate student funded by this grant.

*The $\boldsymbol{e}$-Xtra logo stands for "electronic extra" and indicates that one supplementary table and one supplementary figure are published online.

The author(s) declare no conflict of interest.

(C) 2019 The American Phytopathological Society effector that elicits HR in any genotype with $X v 3$ gene. (Jones et al. 1995,1998 ). The T3 strains identified so far belong to $X$. perforans. $X$. perforans strains containing another effector xopJ4 (previously called $a v r X v 4$ ) but lacking $a v r X v 3$ that induces an HR in Solanum pennelli LA716 and any other tomato genotype with RxopJ4 (Xv4)resistant locus were designated as race T4 (Astua-Monge et al. 2000; Stall et al. 2009; Sharlach et al. 2013).

The Xanthomonas pathogen is introduced into tomato fields through contaminated seed, infested equipment or workers' hands, and wind-driven or rain-splashed plant material or debris (Bashan et al. 1982; Burlakoti et al. 2018; Cuppels et al. 2006; Jones et al. 1986). Integration of cultural practices and chemicals, such as copper, antibiotics (e.g., streptomycin), and plant activators, has been used to manage bacterial spot (Louws et al. 2001; Thayer and Stall 1962; Vallad and Goodman 2004). However, copper- and streptomycin-tolerant strains have been widely reported in Canada, Brazil, Tanzania, and the United States (Abbasi et al. 2015; Araújo et al. 2012; Mixon 2012; Shenge et al. 2014; Vallad et al. 2013). Although tomato growers in NC have reported a failure of copper and streptomycin to manage bacterial spot disease in tomato (F. J. Louws, unpublished data), Xanthomonas strains' tolerance to these chemicals has not been investigated.

The evolution of new Xanthomonas spp. and pathogenic races over time has hindered the development and deployment of host resistance to manage bacterial spot disease in tomato (Timilsina et al. 2016). Among the four species of the genus Xanthomonas, $X$. euvesicatoria and $X$. vesicatoria are distributed worldwide, whereas $X$. perforans and $X$. gardneri are mostly reported from North America and South America (Potnis et al. 2015). X. gardneri was reported in 1991 in the Midwest of the United States (Ma et al. 2011) and Canada on a contaminated seed lot (Cuppels et al. 2006). Although $X$. vesicatoria is widely distributed in the Midwest of the 
United States, it was never a problem in Florida (FL) and the Southeastern United States (Louws et al. 1995). For example, $X$. euvesicatoria was the only species present as race 1 in FL until 1991 before the $X$. perforans race T3 was reported (Timilsina et al. 2015). X. perforans race T4 evolved in 1998 (Astua-Monge et al. 2000; Minsavage et al. 2003), and thereafter, it has been detected more frequently in FL. $X$. perforans race T4 was detected throughout FL, where races T4 and T3 were in the ratio of 3:1 in the previous surveys, indicating a major shift in the race within $X$. perforans populations (Horvath et al. 2012). It is imperative to investigate the pathogen species, race structure, and genetic diversity to develop effective disease management and breeding strategies against the disease in NC.

The antibiotic streptomycin has been extensively used since the early 1950s to manage bacterial spot of tomato and pepper (Thayer and Stall 1962). Because of the evolution of streptomycin-tolerant Xanthomonads, copper-based bactericides began to be used in the late 1960s (Marco and Stall 1983; Thayer and Stall 1962). To enhance the efficacy of copper bactericides, combinations of copper with ethylene bisdithiocarbamate fungicides, such as maneb or mancozeb, have been adopted to increase the availability of free copper ions (Conover and Gerhold 1981; Jones and Jones 1985; Marco and Stall 1983). However, copper-mancozeb tank mixes seemed to be ineffective to manage bacterial spot when copper-tolerant strains are prevalent (Jones and Jones 1985; Obradovic et al. 2005). In NC, most growers continue to use the mancozeb-copper tank mixes for up to five applications before harvest commences and based on extension recommendations (Kuhar et al. 2019). Although this management practice is common, the efficacy of this seems to be failing, and there is a need to characterize the Xanthomonas populations. We hypothesize that $X$. perforans strains in NC would possess tolerance to copper and streptomycin owing to their extensive use in the fields and greenhouses. We also predicted that $X$. perforans is the dominant bacterial spot pathogen of tomato in NC based on population genetic analysis in the Southeastern United States (Potnis et al. 2015; Timilsina et al. 2015; Vallad et al. 2013). We also tested the hypothesis that $X$. perforans strains from NC are predominantly clonal and genetically similar to strains of $X$. perforans from FL. The main objectives of this study were to (i) evaluate strains of Xanthomonas species from tomato for tolerance to copper and streptomycin, (ii) assess the genetic diversity of Xanthomonas strains using BOX repetitive element PCR (BOXPCR) assay and determine the species structure in NC, (iii) characterize the pathogenic races of Xanthomonas strains in NC, and (iv) determine and compare the phylogenetic relationships and genetic distinctness of Xanthomonas strains from NC with the reported Xanthomonas strains from other regions.

\section{MATERIALS AND METHODS}

Sample collection and pathogen isolation. The western region is the major tomato-producing region in $\mathrm{NC}$, in which eight counties were surveyed using a modified random sampling scheme in 2015 and 2016 (Fig. 1). Twenty bacterial spot-infected leaves (four leaves from five sites within the field in random quadrants) were collected per field and placed in a plastic sealable bag. These bags were labeled with the date of collection, location, and tomato cultivar and brought to the laboratory for isolation. To isolate the bacterial pathogen, the infected leaves were surface sterilized with $10 \%$ Clorox (Clorox Company) for $30 \mathrm{~s}$ and rinsed with sterile distilled water (SDW) three times. Fresh lesions were cut at $\sim 4 \mathrm{~mm}^{2}$ with a sterile scalpel in the presence of SDW, streaked on Difco yeast dextrose agar (YDC) medium, and incubated at $27^{\circ} \mathrm{C}$ for $48 \mathrm{~h}$. The plates were examined for the presence of yellow mucoid colonies, and only putative Xanthomonas colonies were subcultured on fresh YDC plates to obtain pure cultures. In total, 290 strains of Xanthomonas species ( $n=163$ in 2015 and $n=127$ in 2016) were isolated from 23 fields across eight counties of NC. All pure cultures were stored in $30 \%$ glycerol at $-80^{\circ} \mathrm{C}$ for future studies (Supplementary Table S1).

Copper and streptomycin tolerance assays. The original work was done with copper tolerance using copper sulfate $\left(\mathrm{CuSO}_{4}\right)$ at $200 \mu \mathrm{g} / \mathrm{ml}$ (Stall et al. 1986) and streptomycin sulfate at $100 \mu \mathrm{g} / \mathrm{ml}$ (Ritchie and Dittapongpitch 1991) that inhibited the growth of the strains of $X$. euvesicatoria from tomato and pepper in the United States. To assess strain tolerance to copper, we used a discriminatory dose of $\mathrm{CuSO}_{4}$ at $200 \mu \mathrm{g} / \mathrm{ml}$ to distinguish between the tolerant strains using positive and negative controls as described previously (Burlakoti et al. 2018; Stall et al. 1986). Likewise, streptomycin

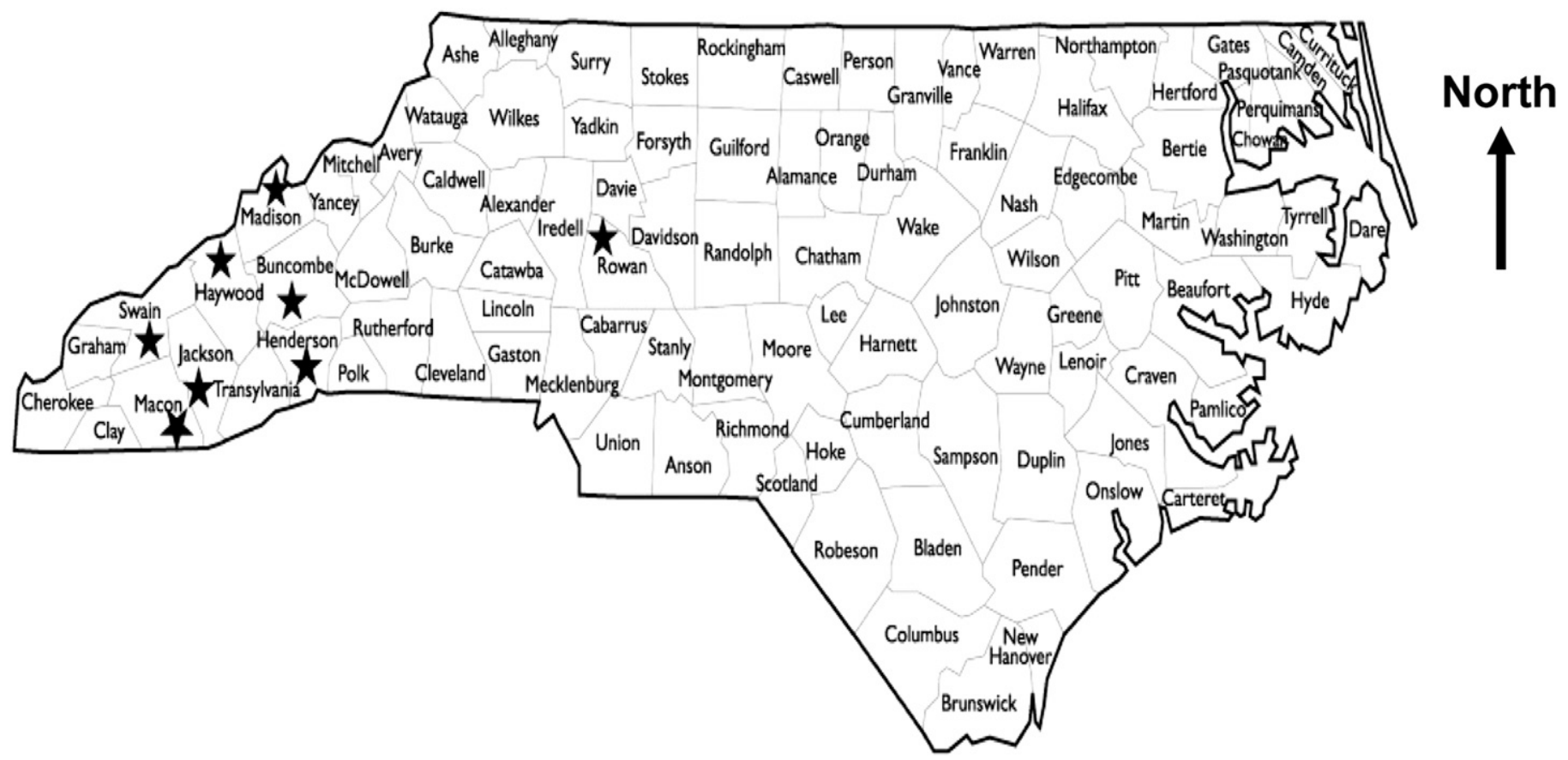

Fig. 1. Map of North Carolina showing counties (star symbols) from where strains of Xanthomonas perforans were collected and analyzed in this study. 
sulfate at the recommended discriminatory dose $(100 \mu \mathrm{g} / \mathrm{ml})$ (Ritchie and Dittapongpitch 1991) was used to discriminate between sensitive and tolerant strains. The $\mathrm{CuSO}_{4}$ ions and streptomycin sulfate dry (Sigma-Aldrich Corporation) were obtained, and sensitivity assays for 290 strains were performed in vitro in sucrose peptone agar (SPA) medium. The SPA medium was prepared using $15.0 \mathrm{~g}$ of sucrose, $5.0 \mathrm{~g}$ of peptone, $0.50 \mathrm{~g}$ of dibasic potassium phosphate, $0.25 \mathrm{~g}$ of magnesium sulfate, and $15.0 \mathrm{~g}$ of Difco agar in $1,000 \mathrm{ml}$ of distilled water. The $\mathrm{pH}$ was adjusted to 7.2 to 7.4 before autoclaving. Fresh stock solution of copper sulfate and streptomycin sulfate was prepared and filter sterilized using a $0.22-\mu \mathrm{m}$-pore size filter under laminar flow. The appropriate amounts of stock solutions of copper and streptomycin were added to the SPA medium after autoclaving and cooled. Bacteria were cultured in Luria-Bertani medium (Thermo Scientific) for 24 to $48 \mathrm{~h}$ and suspended in sterile water to adjust the concentration to $10^{8} \mathrm{CFU} / \mathrm{ml}$. Concentrations were measured using a spectrophotometer at $A_{600}=0.3$ optical density (OD). A 5- $\mu$ l aliquot of the suspension was pipetted and spread on the SPA medium amended with different concentrations of copper and streptomycin and incubated for 24 to $48 \mathrm{~h}$ at $27^{\circ} \mathrm{C}$. The growth of the bacteria on amended medium was visually observed and recorded. Strains capable of growing on SPA medium containing $200 \mathrm{ppm}$ of $\mathrm{CuSO}_{4}$ or $100 \mathrm{ppm}$ of streptomycin sulfate were considered as copper tolerant $(\mathrm{Cu}-\mathrm{T})$ and streptomycin tolerant $(\mathrm{Sp}-\mathrm{T})$, respectively. No bacterial growth on amended media was regarded as copper sensitive $(\mathrm{Cu}-\mathrm{S})$ and streptomycin sensitive $(\mathrm{Sp}-\mathrm{S})$. David Ritchie, Department of Entomology and Plant Pathology, North Carolina State University (Raleigh, NC) provided control strains of Xanthomonas spp. known to be sensitive and tolerant to copper and streptomycin, which were Xcv 611 (Cu-T, Sp-S), Xcv 43 (Cu-T, $\mathrm{Sp}-\mathrm{T})$, and Xcv 135 (Cu-S, Sp-S).

Genetic diversity analysis. BOX-PCR assay was selected for the genetic diversity analysis, because this assay is robust and yields more amplifications compared with enterobacterial repetitive intergenic consensus (ERIC)-PCR and repetitive extragenic palindromic (REP)-PCR assays (Louws and Cuppels 2001; Louws et al. 1995) in our preliminary study. Importantly, BOX-PCR (BOXA1R: 5'-CTACGGCAAGGCGACGCTGACG-3') assay has been successfully utilized for the characterization of bacterial pathogens infecting tomatoes (Araújo et al. 2017). Genomic DNA of each strain was extracted as described previously (Pitcher et al. 1989; Rademaker and de Bruijn 1997) and quantified using a NanoDrop 2000 Spectrophotometer (Thermo Scientific). Final DNA concentration was adjusted to $10 \mathrm{ng} / \mu \mathrm{l}$. BOX-PCR amplification was performed in a $25-\mu$ l reaction mixture as described previously (Louws and Cuppels 2001; Louws et al. 1995) with some modifications. Briefly, one initial cycle of denaturation at $95^{\circ} \mathrm{C}$ for $5 \mathrm{~min}$ was carried out followed by 40 cycles of denaturation at $95^{\circ} \mathrm{C}$ for $30 \mathrm{~s}$, annealing at $48^{\circ} \mathrm{C}$ for $1 \mathrm{~min}$, extension at $68^{\circ} \mathrm{C}$ for $10 \mathrm{~min}$, and a final cycle of extension at $68^{\circ} \mathrm{C}$ for $10 \mathrm{~min}$. The PCR products were separated by gel electrophoresis on $1.5 \%$ agarose (Genesee Scientific Corporation) containing ethidium bromide $(10 \mathrm{mg} / \mathrm{ml}$; Sigma-Aldrich) in $1 \times$ Tris-acetate-EDTA (Thermo Scientific) at $35 \mathrm{~V}$ for 10 to $12 \mathrm{~h}$. The gel image was visualized using a gel documentation system (BioRad Gel Doc). Among 293 strains in our original collections, DNA quality of five strains (NC-278, NC302 , NC-312, NC-316, and NC-351) was found poor at the time of analysis. Thus, only 288 strains were analyzed with BOX-PCR assay. A hierarchical agglomerative cluster analysis was performed to generate clusters from Euclidean distance matrices using SciPy cluster package in python (Jones et al. 2014). Briefly, fingerprint profiles were scored visually: " 0 " for the absence of the band and " 1 " for the presence of the band to generate a binary matrix. The fingerprint profiles were analyzed to identify unique haplotypes. The linkage method with group average (unweighted pair group) method was used to define the hierarchical clustering by comparing data points, and cophenetic correlation coefficient was calculated to determine how well the cluster dendrogram preserves the original distances between data points (Saraçli et al. 2013).

Multiplex quantitative real-time PCR. To determine species structure, a subset of representative strains $(n=45)$ was selected based on BOX-PCR fingerprinting profile, copper and streptomycin sensitivity assays, and the geographical regions (Table 1). Although both $h r c N$ and $h r p B 7$ genes are the same operon and close to each other, the correct gene name is $h r c N$. Four species-specific probes and two primer sets targeting the hrp operon region were designed, and a highly conserved $h r c N$ gene was amplified by multiplex TaqMan quantitative PCR (qPCR) (Strayer et al. 2016). Reference strains $X$. euvesicatoria Xe 157, X. gardneri $X g$ GA2, X. perforans $X p 1484$, and $X$. vesicatoria $X v 144$ were included in the analysis (Strayer et al. 2016). For multiplex qPCR assay, the probes specific for $X$. euvesicatoria, $X$. vesicatoria, $X$ gardneri, and $X$. perforans were labeled with blue, purple, red, and green dye, respectively.

Race identification. The strains used in determining species structure were selected (Table 1), and their ability to cause disease reactions on tomato and pepper differential cultivars was evaluated as described previously (Stall et al. 2009). The tomato differentials used for virulence assay were Bonny Best (susceptible to all races), Hawaii 7998 (effective against avrRxv; race T1), and FL 216 (effective against $a v r X v 3$; race T3). The resistant genotype LA716 carrying the RxopJ4 gene against the XopJ4 effector of race T4 could not be used as a tomato differential because of the extreme necrosis observed in this genotype (Astua-Monge et al. 2000). In addition, four pepper differentials were included for elicitation of an HR on Early Calwonder (ECW) plants and the near-isogenic lines (ECW-10R, ECW-20R, and ECW-30R) containing resistance genes to bacterial spot (Bs1,Bs2, and Bs3, respectively) (Jones et al. 1998; Sahin and Miller 1998). Bacterial inoculum was prepared by suspending a culture grown on nutrient agar for $24 \mathrm{~h}$ at $28^{\circ} \mathrm{C}$ in $\mathrm{SDW}$, and the concentration was adjusted to $\sim 5 \times 10^{8} \mathrm{CFU} / \mathrm{ml}\left(A_{600}=\right.$ 0.3 OD). Reference strains $X$. euvesicatoria E3 and $X$. perforans 91-118 (Hert et al. 2009) obtained from Jeff Jones, Department of Plant Pathology, University of Florida (Gainesville, FL) were used as controls for race $\mathrm{T} 1$ and race $\mathrm{T} 3$, respectively. Bacterial suspensions were infiltrated into the abaxial leaf surfaces with the aid of a 1-ml hypodermic syringe without a needle on 5-week-old tomato and pepper seedlings. To identify pathogenic races, the disease reactions on tomato and pepper differentials were examined for $\mathrm{HR}$ after $24 \mathrm{~h}$ and susceptible reaction up to 2 days after infiltration. HR was characterized by tissue collapse at the infiltration site followed by confluent tissue necrosis occurring up to $24 \mathrm{~h}$ after infiltration (Klement and Goodman 1967). Susceptible or non-HR was confirmed by necrotic spots surrounded with chlorotic halos 3 to 4 days postinfiltration (Burlakoti et al. 2018; Stall et al. 2009). Classification of tomato races (T1 to T4) was assessed according to HR or susceptible reactions on tomato and pepper differentials as described previously (Burlakoti et al. 2018; Stall et al. 2009).

Multilocus sequencing analysis. A subset of 45 representative strains of $X$. perforans as determined by BOX-PCR, geographic location, cultivar, and year of isolation was subjected to multilocus sequencing analysis (MLSA) using the six housekeeping genes as described previously (Almeida et al. 2010; Timilsina et al. 2015). These included elongation factor G ( fusA), glyceraldehyde-3phosphate dehydrogenase A ( gapA), citrate synthase ( $g l t A)$, gyrase subunit B ( gyrB), ABC transporter sugar permease (lacF), and GTP binding protein (lepA) (Almeida et al. 2010; Timilsina et al. 2015). Briefly, the amplification was performed in a $50 \mu \mathrm{l}$ of PCR mixture consisting of $2.5 \mathrm{U}$ of Phuson high-fidelity polymerase (Biorad), $1 \times$ Taq buffer, $0.2 \mathrm{mM} \mathrm{dNTP}, 0.4 \mu \mathrm{m}$ of each forward and reverse primers, and water in a Peltier element-based thermocycle. We used two-step cycling with high-fidelity Phusion polymerase, and therefore, there was no annealing step. 
One initial cycle of denaturation at $98^{\circ} \mathrm{C}$ for 2 min was carried out followed by 35 cycles of denaturation at $98^{\circ} \mathrm{C}$ for $20 \mathrm{~s}$ and extension at $72^{\circ} \mathrm{C}$ for $1 \mathrm{~min}$ and a final cycle of extension at $72^{\circ} \mathrm{C}$ for $10 \mathrm{~min}$. A $4-\mu \mathrm{l}$ PCR product was confirmed by electrophoresis on a $1.0 \%$ agarose gel, and image was visualized using a gel documentation system (BioRad). Positive PCR products were submitted for Sanger platinum sequencing at the Genomic Sciences Laboratory, North Carolina State University (Raleigh, NC). In a separate study, a subset of strains $(n=13)$ used for MLSA was sequenced to confirm the presence of three principal copper tolerance genes $\operatorname{cop} L, \operatorname{cop} A$, and $\operatorname{copB}$ and the $a v r X v 3$ and $a v r X v 4$ genes in the strains as described previously (Astua-Monge et al. 2000; Behlau et al. 2013; Timilsina et al. 2016).

The sequences of six loci were phylogenetically compared with reference Xanthomonas strains publicly available in sequence databases of the Plant Associated and Environmental Microbes Database (PAMDB; http://genome.ppws.vt.edu/cgi-bin/ MLST/home.pl) (Almeida et al. 2010) or the NCBI (https:// www.ncbi.nlm.nih.gov/). Briefly, the nucleotide sequences for each gene were trimmed at both ends such that the final sizes of genes were 591 positions for $f u s A, 444$ positions for gapA, 501 positions for gltA, 411 positions for $g y r B, 408$ positions for $l a c F$, and 390 positions for lepA. Individual gene sequences were concatenated in the alphabetical order of the six genes to give the total length of 2,745 positions (i.e., 1 to 591 for fusA, 592 to 1,035 for gapA, 1,036 to 1,536 for $g l t A, 1,537$ to 1,947 for $g y r B, 1,948$ to 2,355 for $l a c F$, and 2,356 to 2,745 for lepA. The concatenated sequences of six loci of 31 strains that had full sequences of all genes of $X$. perforans from NC and the concatenated sequences of Xanthomonas reference strains were aligned using MUSCLE within Molecular Evolutionary Genetics Analysis (MEGA) software version 7.0 (Kumar et al. 2016). The six housekeeping gene sequences for reference strains Xp ICMP16690 (strain 767), Xv-ATCC 11551 (strain 196), Xe 85-10 (strain 162), and Xg ICMP16689 (strain 766) were imported from the PAMDB, whereas the gene sequences for reference strains Xp GEV839 (accession no. JZVK00000000), Xp 91-118 (accession no. CP019725.1), Xp 17-12 (accession no. JZVH00000000), and Xp 4-20 (accession no. JZUZ00000000) were imported from their whole-genome sequences in the NCBI database. The individual gene sequences of atypical Nigerian strain

TABLE 1. Characteristics of representative strains of Xanthomonas perforans collected from North Carolina from 2015 to 2016 that were selected to determine race profiles

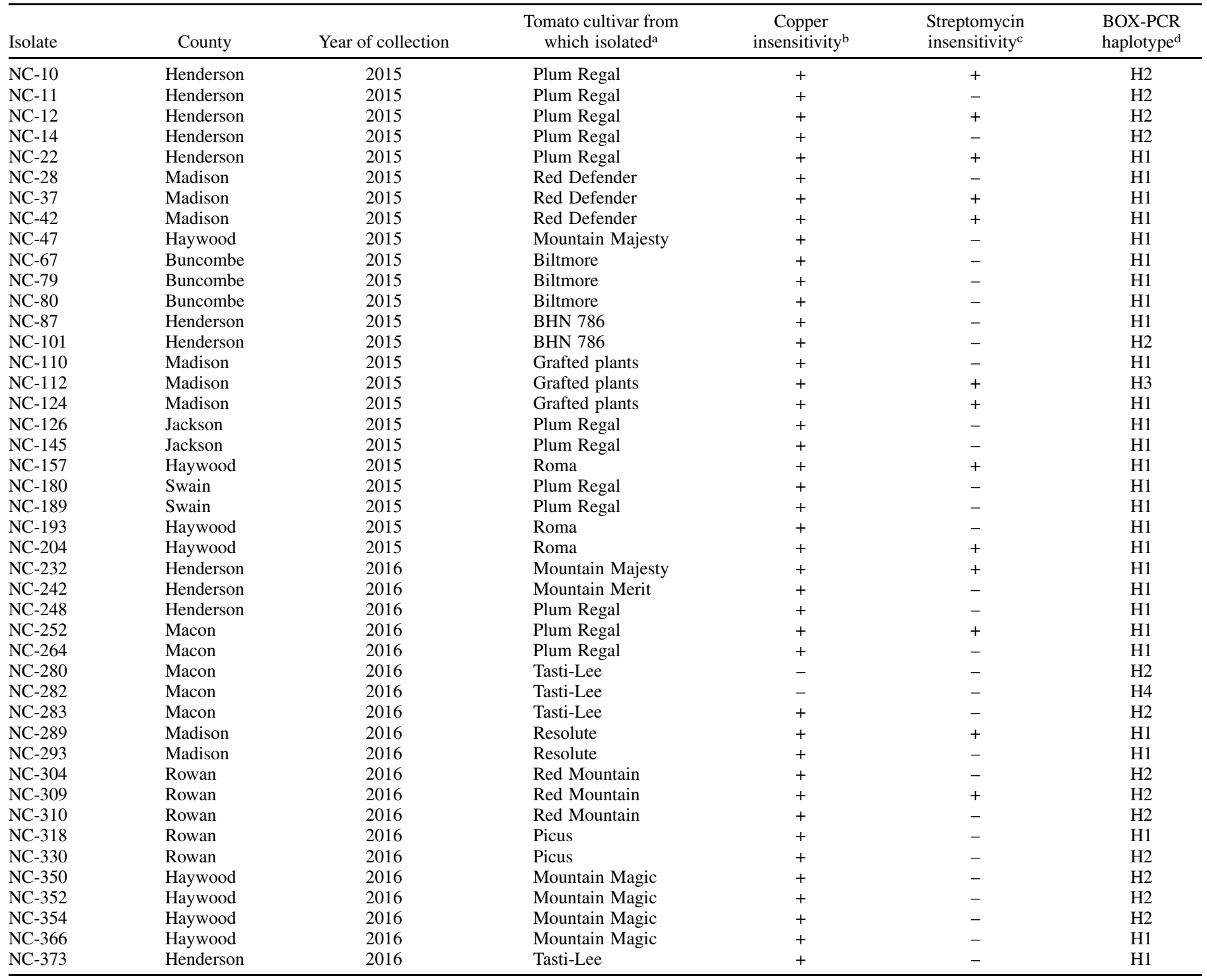

a Tomato cultivar from which $X$. perforans strains were isolated.

b Copper insensitivity of each strain; + indicates copper insensitive, and - indicates copper sensitive.

c Streptomycin insensitivity of each strain; + indicates streptomycin insensitive, and - indicates streptomycin sensitive.

${ }^{d}$ Haplotype of each strain based on BOX repetitive element PCR (BOX-PCR) assay. 
Xs NI1 (i.e., fusA [accession no. KJ938581.1], gapA [accession no. KJ938588.1], gltA [accession no. KJ938595.1], gyrB [accession no. KJ938602.1], lacf [accession no. KJ938629.1], and lepA [accession no. KJ938636.1]) were downloaded from the NCBI. All gene sequences of NC strains were deposited to GenBank (accession nos. MH887556 to MH887747). Phylogenetic analysis based on concatenated gene sequences was analyzed using the maximum likelihood method within MEGA software version 7.0 (Kumar et al. 2016). The general time-reversible model with $\gamma$-distributed invariant sites was used to construct maximum likelihood trees with 1,000 bootstrap replicates. Haplotypes for each gene were determined based on the alignment files and the presence of single-nucleotide polymorphism (SNP) variations among haplotypes. The phylogenetic relationships of the strains along with other metadata, such as geographic location, BOX-PCR profile, race profile, and copper and streptomycin sensitivity, were analyzed using T-BAS v2 (Carbone et al. 2016).

\section{RESULTS}

Copper and streptomycin sensitivity assays. More than $95 \%$ (161 of 163 in 2015 and 123 of 127 in 2016) of strains were tolerant to copper in both years, whereas $45 \%$ (73 of 163) and $25 \%$ ( 32 of 127) of the strains were tolerant to streptomycin in 2015 and 2016, respectively (Fig. 2A). Data suggested that the distribution of copper-tolerant strains was uniform across year and counties, and $100 \%$ of the all locations had copper-tolerant strains in both years. However, the distribution of streptomycin-tolerant strains was not as uniform throughout the counties and years of samplings compared with copper resistance. A lower percentage of streptomycin-tolerant strains was observed in 2016 compared with 2015 (Fig. 2B and C). No streptomycin-tolerant strains were observed in Haywood County in 2016 , but $83 \%$ of strains were tolerant to streptomycin in the same county in the year 2015. Strains susceptible to both copper and streptomycin were not observed in 2015 , but there were five strains susceptible to both copper and streptomycin in 2016 (Fig. 2D).

Genetic diversity analysis. Despite repeated experiments, 10 strains (NC-98, NC-175, NC-176, NC-182, NC-184, NC-198, NC205, NC-234, NC-359, and NC-368) either did not amplify or yielded faint bands with BOX-PCR primer. Thus, BOX-PCR data for only 278 strains were included in this study. BOX-PCR fingerprinting generated 13 amplicons ranging from $300 \mathrm{bp}$ to $2 \mathrm{~kb}$, and four haplotypes $(\mathrm{H} 1, \mathrm{H} 2, \mathrm{H} 3$, and $\mathrm{H} 4)$ were detected (Table 1). Among them, nearly $93 \%$ of the strains were $\mathrm{H} 1,6.5 \%$ of strains were $\mathrm{H} 2$, and one strain each was as an $\mathrm{H} 3$ and $\mathrm{H} 4$ haplotype (Tables 1 and 2). The $\mathrm{H} 1$ was detected in all eight counties in both years. The H2 was detected in Henderson County in 2015 and Macon, Rowan, and Haywood Counties in 2016 (Table 1). The one H3 strain was found in Madison County in 2015, whereas the H4 was isolated from Macon County in 2016 (Table 1).

Multiplex real-time qPCR. The qPCR assay of representative strains targeting the highly conserved $h r c N$ gene identified Xanthomonas strains from tomato in $\mathrm{NC}$ as a single species, $X$. perforans. The detection of only green fluorescence except for reference strains $X e 157, X v 144$, and $X g$ GA2 confirmed that all of the strains examined were $X$. perforans (Supplementary Fig. S1).

Race identification. The majority of representative strains of $X$. perforans induced HR on all four pepper differentials (Table 3), indicating that they are not pepper races. Four strains (NC-79, NC80, NC-112, and NC312) induced HR on FL 216 and belonged to race T3 (Table 3). The remaining strains did not induce HR on both HI 7998 and FL 216, indicating that they all belong to race T4. The Xp91-118 and Xe E3 strains and water reactions were as expected.

MLSA. Phylogenetic analysis revealed that all strains of $X$. perforans from NC were grouped with the reference $X$. perforans strains from FL (Fig. 3A). No variation was observed among sequenced $X$. perforans strains in fusA, lacF, and lepA gene sequences, whereas two, three, and four haplotypes were observed among the gltA, gyrB,
A

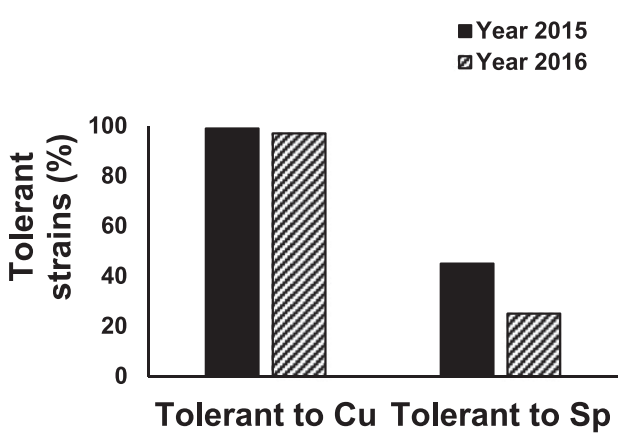

C

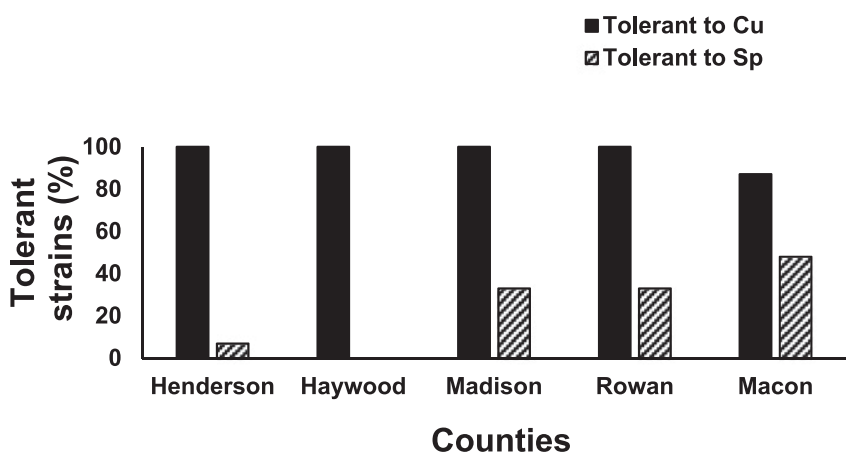

B

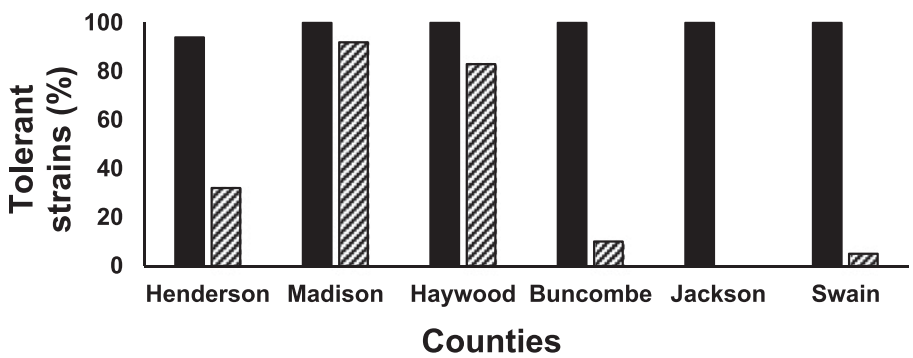

D

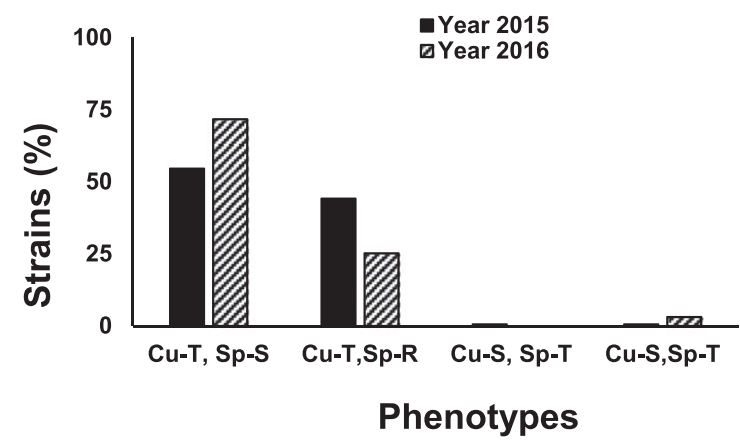

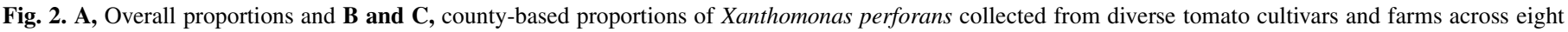

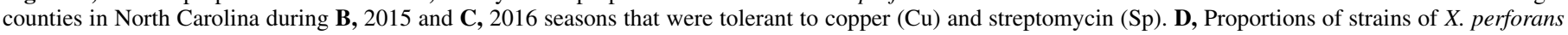

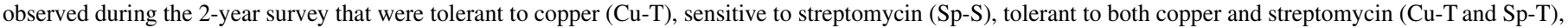
sensitive to both copper and streptomycin $(\mathrm{Cu}-\mathrm{S}$ and $\mathrm{Sp}-\mathrm{S})$, and tolerant to streptomycin (Sp-T) but sensitive to copper (Cu-S). 
and gapA gene sequences, respectively (Table 4). Strain NC-282 showed an SNP variation at nucleotide sites 27 and 78, which placed it with X. euvesicatoria-type strain 85-10 (isolated from FL in 1985) based on gltA sequences (data not shown) (Timilsina et al. 2015). The gyrB gene differentiated strains of $X$. perforans into two groups: 23 strains grouped with $X$. perforans reference strains GEV839 (isolated from FL in 2012), 4-20 (isolated from FL in 2006), and X. euvesicatoria-type strain 85-10, whereas 18 strains grouped with $X$. perforans-type strains ICMP 16690767 (isolated from FL in 1991), 17-12 (isolated from FL in 2006), and 91-118 (isolated from FL in 1991; data not shown) (Timilsina et al. 2015). The gapA gene differentiated strains of $X$. perforans into three groups: 24 strains grouped with $X$. perforans reference strain GEV839 and X. euvesicatoria reference strain 85-10, 9 strains were grouped with $X$. perforans reference strain 17-12, and 5 strains were grouped with $X$. perforans reference strains ICMP 16690 767, 4-20, and 91-118 (data not shown). The number of segregating sites and their nucleotide positions for these genes were estimated for each locus, and gapA had more mutation or loss and yielded more haplotypes compared with other loci (Table 4).

Based on the concatenated sequences of six loci, strains of $X$. perforans were divided into two groups: $41 \%$ of the strains were in G1, whereas $59 \%$ strains belonged to G2. G1 was further differentiated into three subgroups: G1-A (25\% of total), G1-B (13\%), and G1-C (3\%) (Fig. 3A). These groups corresponded to four haplotypes $(\mathrm{H} 1, \mathrm{H} 2, \mathrm{H} 3$, and H4) based on seven segregating sites as detected on the concatenated sequences of six loci (Table 5). $\mathrm{H} 1$ corresponded to group 2, whereas $\mathrm{H} 2, \mathrm{H} 3$, and $\mathrm{H} 4$ corresponded to group 1 (Table 5). The $\mathrm{H} 1$ in group 2 differed from $\mathrm{H} 2, \mathrm{H} 3$, and $\mathrm{H} 4$ in group 1 by four, five, and seven SNPs, respectively. In group 1, H2 differed from $\mathrm{H} 3$ and $\mathrm{H} 4$ by one and three SNPs, respectively. The $\mathrm{H} 3$ differed from the $\mathrm{H} 4$ by two SNPs. Most NC strains were similar to the $X$. perforans $\mathrm{T} 4$ strain GEV839 isolated from FL in 2012 (Timilsina et al. 2016) and were grouped in $\mathrm{G} 2$ (Fig. 3B). NC strain G1-A was similar to the $X$. perforans T4 reference strain 17-12 isolated from FL in 2006 (Fig. 3B) (Timilsina et al. 2015). Only four strains were grouped into G1-B and similar to the reference strain $X$. perforans $91-118$ from FL in 1991 (Timilsina et al. 2015) and ICMP16690-767. The strain NC-282 was placed under G1-C (Fig. 3B). Whole-genome sequencing of representative strains confirmed the presence of the CopLAB gene cluster and the $a v r X v 4$ gene but the absence of the $a v r X v 3$ gene in those strains of $X$. perforans in NC (data not shown). Partial sequences were submitted to GenBank (accession nos. for the $\operatorname{cop} L A B$ gene cluster: MK616431 to MK616466 and accession nos. for the avrXv4 gene: MK583017 to MK583029).

\section{DISCUSSION}

We have combined conventional methods and multilocus sequencing approaches to rapidly gain information on phenotypic and genetic diversity of Xanthomonas strains causing bacterial spot disease of tomato in $\mathrm{NC}$ for the first time in a systematic manner. Assay results demonstrated that there is a widespread existence of copper resistance and a modest level of streptomycin resistance in $X$. perforans in NC. The higher incidence of bacterial strains resistant to copper than streptomycin observed indicates that there has been more selection pressures for copper resistance, consistent with continuous copper use in the early field season compared with only two applications of streptomycin (typically) in the greenhouse before field setting. In planta virulence on tomato and pepper differentials indicates that the majority of $X$. perforans strains belong to race $\mathrm{T} 4$ followed by race $\mathrm{T} 3$.

Widespread existence of copper-tolerant strains had been reported in Canada (Abbasi et al. 2015), Tanzania (Shenge et al. 2014), and the United States (Mixon 2012). Both copper- and

TABLE 2. Amplicon detection in each haplotype of Xanthomonas perforans strains collected in North Carolina in 2015 and 2016 generated by BOX repetitive element PCR (BOX-PCR)

\begin{tabular}{|c|c|c|c|c|c|c|c|c|c|c|c|c|c|c|c|c|}
\hline \multirow[b]{2}{*}{ Haplotype } & \multicolumn{13}{|c|}{ Amplicon detected in each haplotype ${ }^{a}$} & \multirow[b]{2}{*}{ Year $^{\mathrm{b}}$} & \multirow[b]{2}{*}{ County ${ }^{\mathrm{c}}$} & \multirow[b]{2}{*}{ No. of strains analyzed } \\
\hline & 1 & 2 & 3 & 4 & 5 & 6 & 7 & 8 & 9 & 10 & 11 & 12 & $\overline{13}$ & & & \\
\hline H1 & 1 & 1 & 1 & 1 & 1 & 1 & 1 & 1 & 1 & 1 & 1 & 1 & 1 & 2015,2016 & All 8 counties & 258 \\
\hline $\mathrm{H} 2$ & 1 & 1 & 1 & 0 & 1 & 1 & 1 & 1 & 1 & 1 & 1 & 1 & 1 & 2015,2016 & Henderson, Macon, Haywood, Rowan & 18 \\
\hline $\mathrm{H} 4$ & 0 & 0 & 0 & 0 & 0 & 0 & 0 & 0 & 1 & 0 & 1 & 0 & 0 & 2016 & Macon & 1 \\
\hline
\end{tabular}

${ }^{a}$ Here, 1 represents the presence of a particular amplicon, and 0 represents the absence of a particular amplicon in the given haplotype.

$\mathrm{b}$ Year of isolation of the strains belonging to each haplotype.

c Counties from where the strains were collected.

d Total number of strains belonging to each haplotype.

TABLE 3. Identification of pathogenic races of representative strains of Xanthomonas perforans from North Carolina by inoculating on tomato and pepper differential cultivars and lines

\begin{tabular}{|c|c|c|c|c|c|c|c|c|c|}
\hline \multirow[b]{2}{*}{ Strains } & \multicolumn{7}{|c|}{ Differential lines ${ }^{\mathrm{a}}$} & \multirow{2}{*}{$\begin{array}{c}\text { Result of } \\
\text { pathogenicity assay }\end{array}$} & \multirow[b]{2}{*}{ Race score } \\
\hline & HI 7998 & FL 216 & Bonny Best & ECW 10R & ECW 20R & ECW 30R & $\overline{\mathrm{ECW}}$ & & \\
\hline $\begin{array}{l}\text { NC-10, NC-11, NC-12, NC-22, } \\
\text { NC-28, NC-37, NC-42, NC-47, } \\
\text { NC-67,NC-87, NC-101, NC-110, } \\
\text { NC-124, NC-126, NC-145, } \\
\text { NC-157, NC-180, NC-189, } \\
\text { NC-193, NC-204, NC-232, } \\
\text { NC-242, NC-248, NC-252, } \\
\text { NC-264, NC-280, NC-282, } \\
\text { NC-283, NC-289, NC-293, } \\
\text { NC-304, NC-309, NC-310, } \\
\text { NC-318, NC-330, NC-352, }\end{array}$ & & & & & & & & & \\
\hline NC-354, NC-366, NC-373 & - & - & - & + & + & + & + & Tomato & $\mathrm{T} 4$ \\
\hline NC-079, NC-80, NC-112, NC-312 & - & + & - & + & + & + & + & Tomato & T3 \\
\hline Xp 91-118 (control) & - & + & - & + & + & + & + & Tomato & T3 \\
\hline Xe E3 (control) & + & - & - & + & + & - & - & Tomato, pepper & T1 \\
\hline Water & - & - & - & - & - & - & - & & \\
\hline
\end{tabular}


streptomycin-tolerant Xanthomonas spp. populations were reported from Brazil (Araújo et al. 2012), the Caribbean and Central America (Bouzar et al. 1999), Ethiopia (Kebede et al. 2014), and the United States (Thayer and Stall 1962; Vallad et al. 2013). Notably, all fields sampled in NC harbored $X$. perforans strains tolerant to copper, whereas streptomycin-tolerant strains were not observed in some fields. Although Ritchie and Dittapongpitch (1991) reported 63\% copper-tolerant and $30 \%$ streptomycin-tolerant strains of Xanthomonas species in $\mathrm{NC}$, their findings were focused on pepper, and collections from tomato were insignificant.
Most of the genes associated with copper tolerance in plantpathogenic bacteria are plasmid encoded (Basim et al. 2005; Behlau et al. 2012; Cooksey 1987; Richard et al. 2017). Copper tolerance genes in X. campestris pv. vesicatoria strains were detected on 188to 200-kb self-transmissible plasmids $\mathrm{pXvCu}$ and $\mathrm{pXV10a}$ from FL (Bender et al. 1990; Stall et al. 1986). DNA hybridization indicated that the tolerance genes on $\mathrm{pXV} 10 \mathrm{~A}$ and $\mathrm{pXvCu}$ plasmids share nucleotide sequence homology and may have a common origin (Bender et al. 1990). Another 100-kb nonself-transmissible plasmid containing loci for copper tolerance was also discovered in a strain

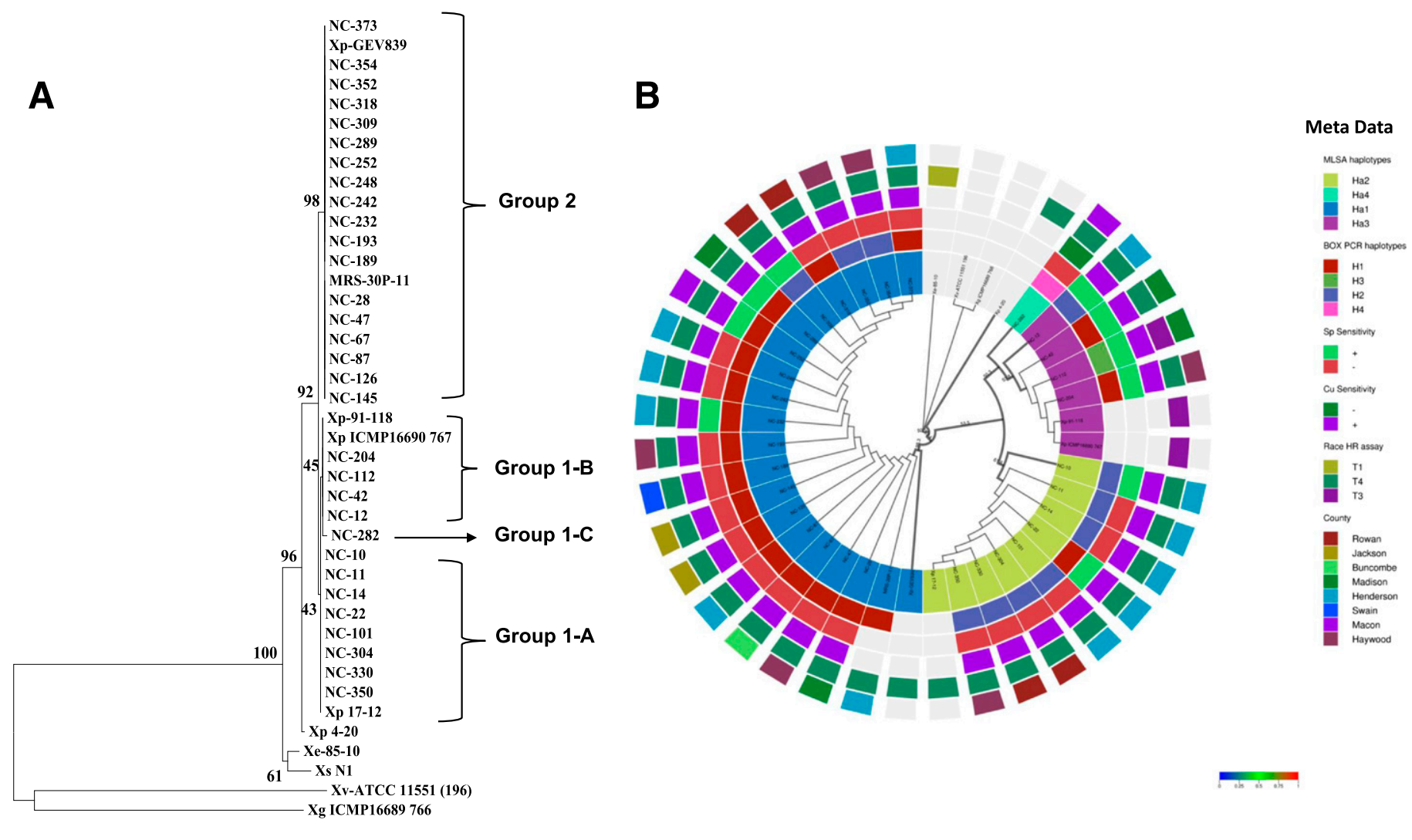

\subsection{0}

Fig. 3. A, Phylogenetic analysis of Xanthomonas perforans strains from North Carolina using concatenated sequences of six genes: elongation factor G (fusA), glyceraldehyde-3-phosphate dehydrogenase A ( gapA), citrate synthase ( gltA), gyrase B ( gyrB), ABC transporter sugar permease (lacF), and GTP binding protein (lepA). B, Combined visualization of counties, BOX-PCR fingerprints, copper and streptomycin sensitivity assays, and race profiles using T-BAS v2. Reference strains of Xanthomonas euvesicatoria, Xanthomonas gardneri, X. perforans, and Xanthomonas vesicatoria were downloaded from the Plant Associated and Environmental Microbes Database and the NCBI database. Values indicate bootstrap values for each branch expressed as percentages. A, The scale bar indicates the number of substitutions per site. B, Branches are shaded to indicate four haplotypes generated from multilocus sequence analysis (MLSA), and rings indicate the metadata. The six housekeeping gene sequences for reference strains Xp ICMP16690 (strain id 767), Xv-ATCC 11551 (strain 196), Xe 85-10 (strain 162), and Xg ICMP16689 (strain 766) were imported from the Plant Associated and Environmental Microbes Database, whereas the gene sequences for reference strains Xp GEV839 (accession no. JZVK00000000), Xp 91-118 (accession no. CP019725.1), Xp 17-12 (accession no. JZVH00000000), and Xp 4-20 (accession no. JZUZ00000000) were imported from their whole-genome sequences in the NCBI database. The individual gene sequences of atypical Nigerian strain Xs NI1 (Xs N1; i.e., fusA [accession no. KJ938581.1], gapA [accession no. KJ938588.1], gltA [accession no. KJ938595.1], gyrB [accession no. KJ938602.1], lacf [accession no. KJ938629.1], and lepA [accession no. KJ938636.1]) were downloaded from the NCBI.

TABLE 4. Sequence statistics of six housekeeping genes in the Xanthomonas perforans strains from North Carolina

\begin{tabular}{lcccc}
\hline Gene sequence $^{\mathrm{a}}$ & Nucleotides (no.) & Haplotypes (no.) & Segregating sites (no.) & Nucleotide position of segregating sites \\
\hline fusA & 591 & 1 & 0 & $\mathrm{n} / \mathrm{a}^{\mathrm{b}}$ \\
gapA & 444 & 3 & 4 & $186,195,283,429$ \\
gltA & 501 & 2 & 2 & 27,78 \\
gyrB & 411 & 2 & 1 & 39 \\
lacF & 408 & 1 & 0 & $\mathrm{n} / \mathrm{a}$ \\
lepA & 390 & 1 & 0 & $\mathrm{n} / \mathrm{a}$ \\
Concatenated & 2,745 & 4 & 7 & $777,786,874,1020,1062,1113,1575$
\end{tabular}

a fusA, elongation factor G; gapA, glyceraldehyde-3-phosphate dehydrogenase A; gltA, citrate synthase; gyrB, gyrase B; lac $F$, ABC transporter sugar permease; lepA, GTP binding protein.

${ }^{\mathrm{b}} \mathrm{n} / \mathrm{a}=$ not applicable. 
from California (Cooksey 1987). Chromosome-encoded copper tolerance gene clusters have also been reported in a 7,652-bp XbaI/ EcoRI chromosomal fragment in $X$. campestris pv. vesicatoria strain XvP26 from Taiwan (Basim et al. 2005). The sequencing of six tomato and pepper copper-tolerant pathogens belonging to different species of the genus Xanthomonas showed that all six strains carried the previously described copper resistance gene system copLAB carried on a conjugative plasmid (Richard et al. 2017). The plasmid was highly conserved among five strains (from 1955 to 2010), suggesting extensive events of horizontal gene transfer at the niche level (Richard et al. 2017). The transfer of plasmids between copper-tolerant and copper-sensitive strains through conjugation has also been demonstrated under laboratory conditions (Stall et al. 1986). Similarly, the presence of a coppertolerant Pseudomonas putida strain with a plasmid-borne cop homolog in a commercial tomato seed lot also suggests that saprophytic bacteria could contribute to the spread of resistant bacterial populations between fields and different geographical areas (Cooksey et al. 1990). The findings of this study indicate that multiple and independent introductions of copper tolerance genes have taken place for $\mathrm{Cu}^{\mathrm{R}}$ strains of $X$. perforans. The $\operatorname{cop} L A B$ gene cluster was responsible for copper tolerance in several other xanthomonads (Behlau et al. 2011, 2012). We hypothesize that different selection pressures and genetic pools providing tolerance determinants and instability of some tolerance determinants (Diancourt et al. 2010) all could contribute to explaining the severe outbreaks of bacterial spot disease in NC. Although we examined only one source of copper (i.e., $\mathrm{CuSo}_{4}$ ) for $X$. perforans strains, evaluating and comparing the efficacy of newly developed copper composites, such as core-shell copper, multivalent copper, and fixed quaternary ammonium copper FQ-Cu (Strayer-Scherer et al. 2018), and understanding mechanisms of copper tolerance in $X$. perforans strains from NC would be potentially useful to manage coppertolerant strains and reduce bacterial spot incidence of tomato.

Evidence for both chromosomal and plasmid-mediated streptomycin tolerance in plant-pathogenic bacteria has been reported (Burr et al. 1988; Minsavage et al. 1990; Springer et al. 2001). Furthermore, streptomycin tolerance might occur at the cellular level either by an alternation of binding affinity of ribosomal proteins for the antibiotic by chromosomal mutations or by modification of the antibiotic by periplasmic enzymes (Davies 1986; Gale et al. 1972). We found that some strains are tolerant or insensitive to streptomycin. Thus, streptomycin tolerance was not as prevalent as copper tolerance. Although the frequency of copper and streptomycin tolerance genes was correlated with repeated loading of the selective chemical agents into the environment (Burr et al. 1988; Canteros 1999; Stall and Thayer 1962), reasons for the existence of inconsistent streptomycin tolerance over years, fields, and counties in $X$. perforans populations in $\mathrm{NC}$ are uncertain. We hypothesize that tolerance plasmid was introduced in seed sources, and the incidence of contaminated seed may vary by seed lot and year. In addition, tomato growers in $\mathrm{NC}$ usually purchase transplants from nurseries instead of growing seedings themselves. It is likely that copper- and streptomycin-tolerant strains have been introduced into different tomato-growing areas in $\mathrm{NC}$ through common transplant nurseries. The prevalence of bacterial spot strains and the incidence of tolerance to copper and streptomycin suggest that future research is need to determine if the strains can persist in the tomato ecosystem from one year to the next or if seed and/or transplants are the primary sources of inoculum and the main carriers for long-distance movement.

Both BOX-PCR fingerprinting and MLSA assays revealed low genetic diversity within $X$. perforans in NC. The MLSA of $X$. perforans populations from NC based on six genes showed the presence of two distinct groups and seemed to be clonal within the lineage, which is consistent with the groups observed in $X$. perforans in FL (Timilsina et al. 2015). The largest group in the phylogenetic tree that contained $59 \%$ of $X$. perforans strains of NC included the T4 strain GEV839 isolated from FL in 2012, suggesting that the majority of $X$. perforans strains in NC are in the same phylogenetic group as that of $X$. perforans strains in FL (Timilsina et al. 2016). Similarly, 25\% of $X$. perforans strains in NC were grouped with $X$. perforans $\mathrm{T} 4$ strain Xp17-12 isolated from FL in 2006. Few $X$. perforans strains in NC (13\%) were grouped with $X$. perforans T3 strain 91-118 and ICMP166690767. The strains NC-12, NC-42, and NC-204, which were detected as race $\mathrm{T} 4$ based on HR assay, were grouped with race T3-type strains in the phylogenetic tree. In addition to strain-level variation, allelic diversification in type III effectors might resolve their race profile (Abrahamiana et al. 2018). However, both results clearly indicate the presence of race T3 strains in NC. The strain NC-282 with Ha4 haplotype based on BOX-PCR was also grouped separately from the rest of the strains in the phylogenetic tree constructed using concatenated sequences of six housekeeping genes in this study. This strain had gltA gene sequence similar to that of $X$. euvesicatoria, whereas the other five gene sequences were similar to that of $X$. perforans. Intriguingly, the strain NC282 was sensitive to both copper and streptomycin. Previously, one atypical Nigerian strain had also been reported that had fusA and gyrB genes identical with $X$. perforans but gltA and $l a c F$ genes identical to $X$. euvesicatoria (Timilsina et al. 2015). Overall, MLSA revealed that $X$. perforans strains in NC were similar to $X$. perforans strains in FL, confirming that $X$. perforans strains from NC might have a common origin to that of FL strains. Results in this study show that genomic fingerprints generated by BOXPCR give a high and rapid level of taxonomic resolution currently achievable by PCR methods (Louws and Cuppels 2001; Louws et al. 1995). It is a tool to rapidly "bin" strains into genetic groups, and then, representative strains can be selected for additional indepth work. Thus, the BOX-PCR method allows us to differentiate the strains even at the intraspecies level, and this technique is more suitable for rapid discrimination of a high number of newly isolated strains of plant pathogens. MLSA indicates the sequencing and concatenation of the housekeeping genes and provides a more robust tree topology and an improved understanding of speciation events in comparison with a tree based only on

TABLE 5. Haplotypes and single-nucleotide polymorphism variation among Xanthomonas perforans strains from North Carolina based on concatenated sequences of six housekeeping genes: elongation factor G $(f u s A)$, glyceraldehyde-3-phosphate dehydrogenase A (gapA), citrate synthase ( $g l t A)$, gyrase B ( gyrB), ABC transporter sugar permease $(l a c F)$, and GTP binding protein $(l e p A)^{\mathrm{a}}$

\begin{tabular}{lcccccccccc}
\hline & \multicolumn{7}{c}{ Nucleotide position (bp) } & & \\
\cline { 2 - 6 } Haplotypes & 777 & 786 & 874 & 1020 & 1062 & 1113 & 1575 & Group & \multicolumn{1}{c}{ Strains } \\
\hline Ha1 & T & G & A & G & A & T & T & G2 & MRS-30P-11, NC-28, NC-47, NC-67, NC-87, NC-126, NC-145, NC-189, \\
& & & & & & & & & NC-193, NC-232, NC-242, NC-248, NC-252, NC-289, NC-309, NC-318, \\
Na2 & G & C & G & G & A & T & C & G1-A & NC-10, NC-11, NC-14, NC-22, NC-101, NC-304, NC-330, NC-350, Xp 17-12 \\
Ha3 & G & C & G & C & A & T & C & G1-B & NC-12, NC-42, NC-112, NC-204, Xp-91-118, Xp ICMP16690-767 \\
Ha4 & G & C & G & C & C & C & C & G1-C & NC-282 \\
\hline
\end{tabular}

${ }^{a}$ Haplotypes are based on multilocus sequencing of six housekeeping genes: fusA (nucleotide positions 1 to 591), gapA (592 to 1035), gltA (1036 to 1536), gyrB (1537 to 1974), lacF (1948 to 2355), and lepA (2356 to 2745). 
BOX-PCR; therefore, we focus on the MLSA data and not on the BOX-PCR data.

Given that we are working solely with $X$. perforans strains, our main interest was strictly in tomato as a host. Thus, one of our goals of this research was to gain insight into the current race profiles of $X$. perforans and their distributions in major tomato-producing areas in NC. Based on the HR host assay, 91 and $9 \%$ of them belonged to races $\mathrm{T} 4$ and $\mathrm{T} 3$, respectively, which indicate that race $\mathrm{T} 3$ has not been completely replaced by race $\mathrm{T} 4$ in $\mathrm{NC}$ as observed in FL (Vallad et al. 2013). X. perforans race T3 was identified first in 1991 in FL (Hert et al. 2005; Tudor-Nelson et al. 2003). Later, strain $X p 4 B$, a tomato race T4, was identified in 1998 from FL, which carries a mutation in the $a v r X v 3$ gene. Studies conducted between 2006 and 2012 identified that the majority of race T4 strains carried either frameshift mutations or transposon insertions in avrXv3 (Horvath et al. 2012). We hypothesize that the emergence of $X$. perforans race $\mathrm{T} 4$ in NC could be owing to the mutations in the avrXv3 gene (Astua-Monge et al. 2000; Horvath et al. 2012). In another study, whole-genome sequencing of the strains used in this study was completed. To genetically confirm tomato race T4, a subset of strains used for MLSA was present in the $a v r X v 4$ gene, which also confirmed the absence of the $a v r X v 3$ gene in those strains. The absence of diversity in NC strains suggested that the $X$. perforans tomato race $\mathrm{T} 4$ is an established population in the Southeastern United States. This similar observation was found in Taiwan (Burlakoti et al. 2018), where the majority of the characterized $X$. perforans strains were identified as race T4. However, only one T4 strain was reported from Ethiopia in 2014 (Kebede et al. 2014). The shifts to new strains and the rapid increase of clonal strains in diverse geographic regions over the years are likely owing to strain movement via global trade. Although our study demonstrated the absence of diversity in $X$. perforans populations from tomato, monitoring bacterial populations over time and space is imperative to generate timely information about the genetic structure of pathogen populations that is relevant to breeding programs and resistance deployment.

In summary, we found that $X$. perforans race $\mathrm{T} 3$ is rarely present, whereas race $\mathrm{T} 4$ is widely distributed in the major tomato-growing regions of western NC. The majority of $X$. perforans strains were tolerant to copper-based bactericide. These results suggest that the use of copper products to manage bacterial spot in tomato would be ineffective in NC and the Southeastern United States. Our study demonstrated low phenotypic and genetic diversity of $X$. perforans populations in NC. Race T4 was common in several tomatogrowing areas in NC, and thus, short-term control strategies should target this population. Tomato growers should implement bestmanagement practices, such as the use of plant activators that induce systemic-acquired resistance (e.g., Acibenzolar-S-methyl or Actigard 50WG; Syngenta Crop Protection), use of biopesticides, use of $X$. perforans-free seed, and host plant resistance (Bhattarai et al. 2017; Louws 2018; McGrath and LaMarsh 2014; Miller et al. 2014; Vallad and Goodman 2004). Effector-based breeding strategies (Timilsina et al. 2016) supported by new genomic tools for deploying multiple $R$ genes in adapted tomato varieties should be exploited to combat emerging races of $X$. perforans in NC and the Southeastern United States as a long-term strategy. Moreover, knowledge of the effector load in the X.perforans populations will also guide strategies for achieving durable resistance to $X$. perforans (Schwartz et al. 2015).

\section{ACKNOWLEDGMENTS}

We thank D. Ritchie (Department of Entomology and Plant Pathology, North Carolina State University) for providing reference strains for sensitivity assays of Xanthomonas perforans and Yeon Yee Oh and Thomas Ingram for technical help. We also thank C. Mauney and J. Zhang (Department of Horticultural Science, North Carolina State University) for assisting in collecting disease samples and helping with the data analysis, respectively.

\section{LITERATURE CITED}

Abbasi, P. A., Khabbaz, S. E., Weselowski, B., and Zhang, L. 2015. Occurrence of copper-resistant strains and a shift in Xanthomonas spp. causing tomato bacterial spot in Ontario. Can. J. Microbiol. 61:753-761.

Abrahamiana, P., Timilsina, S., Minsavage, G. V., KC, S., Goss, E. M., Jones, J. B., and Vallad, G. E. 2018. The type III effector AvrBsT enhances Xanthomonas perforans fitness in field-grown tomato. Phytopathology 108: 1355-1362.

Almeida, N. F., Yan, S., Cai, R., Clarke, C. R., Morris, C. E., Schaad, N. W., Schuenzel, E. L., Lacy, G. H., Sun, X., Jones, J. B., and Castillo, J. A. 2010. PAMDB: A multilocus sequence typing and analysis database and website for plant-associated microbes. Phytopathology 100:208-215.

Araújo, E., Pereira, R., Ferreira, M., Quezado-Duval, A., and Café-Filho, A. 2012. Sensitivity of Xanthomonads causing tomato bacterial spot to copper and streptomycin and in vivo infra-specific competitive ability in Xanthomonas perforans resistant and sensitive to copper. J. Plant Pathol. 94:79-87.

Araújo, E. R., Costa, J. R., Ferreira, M. A., and Quezado-Duval, A. M. 2017. Widespread distribution of Xanthomonas perforans and limited presence of $X$. gardneri in Brazil. Plant Pathol. 66:159-168.

Araújo, E. R., Pereira, R. C., Ferreira, M. A. S. V., Café-Filho, A. C., Moita, A. W., and Quezado-Duval, A. M. 2011. Effect of temperature on pathogenicity components of tomato bacterial spot and competition between Xanthomonas perforans and X. gardneri. Acta Hortic. 914:39-42.

Astua-Monge, G., Minsavage, G. V., Stall, R., Vallejos, C. E., Davis, M., and Jones, J. B. 2000. Xv4-vrxv4: A new gene-for-gene interaction identified between Xanthomonas campestris pv. vesicatoria race T3 and the wild tomato relative Lycopersicon pennellii. Mol. Plant-Microbe Interact. 13: 1346-1355.

Bashan, Y., Diab, S., and Okon, Y. 1982. Survival of Xanthomonas campestris pv. vesicatoria in pepper seeds and roots, in symptomless and dry leaves, in on-host plants and in the soil. Plant Soil 68:161-170.

Basim, H., Minsavage, G. V., Stall, R. E., Wang, J. F., Shanker, S., and Jones, J. B. 2005. Characterization of a unique chromosomal copper resistance gene cluster from Xanthomonas campestris pv. vesicatoria. Appl. Environ. Microbiol. 71:8284-8291.

Behlau, F., Canteros, B. I., Jones, J. B., and Graham, H. J. 2013. Copper resistance genes from different xanthomonads and citrus epiphytic bacteria confer resistance to Xanthomonas citri subsp. citri. Eur. J. Plant Pathol. 133: 949-963.

Behlau, F., Canteros, B. I., Minsavage, G. V., Jones, J. B., and Graham, J. H. 2011. Molecular characterization of copper resistance genes from Xanthomonas citri subsp. citri and Xanthomonas alfafae subsp. citrumelonis. Appl. Environ. Microbiol. 77:4089-4096.

Behlau, F., Jones, J. B., Myers, M. E., and Graham, J. H. 2012. Monitoring for resistant populations of Xanthomonas citri subsp. citri and epiphytic bacteria on citrus trees treated with copper or streptomycin using a new semiselective medium. Eur. J. Plant Pathol. 132:259-270.

Bender, C. L., Malvick, D. K., Conway, K. E., George, S., and Pratt, P. 1990. Characterization of pXV10A, a copper resistance plasmid in Xanthomonas campestris pv. vesicatoria. Appl. Environ. Microbiol. 56:170-175.

Bhattarai, K., Louws, F. J., Williamson, J. D., and Panthee, D. R. 2017. Resistance to Xanthomonas perforans race T4 causing bacterial spot in tomato breeding lines. Plant Pathol. 66:1103-1109.

Bouzar, H., Jones, J., Stall, R., Louws, F., Schneider, M., Rademaker, J., de Bruijn, F. J., and Jackson, L. E. 1999. Multiphasic analysis of Xanthomonads causing bacterial spot disease on tomato and pepper in the Caribbean and Central America: Evidence for common lineages within and between countries. Phytopathology 89:328-335.

Burlakoti, R. R., Hsu, C. F., Chen, J. R., and Wang, J. F. 2018. Population dynamics of Xanthomonads associated with bacterial spot of tomato and pepper during 27 years across Taiwan. Plant Dis. 102:1348-1356.

Burr, T. J., Norelli, J. L., Katz, B., Wilcox, W. F., and Hoying, S. A. 1988. Streptomycin-resistance of Pseudomonas syringae pv. papulans in apple orchards and its association with a conjugative plasmid. Phytopathology 78: 410-413.

Canteros, B. I. 1999. Copper resistance in Xanthomonas campestris pv. citri. Pages 455-459 in: Proceedings of the International Society of Bacteriology. A. Mahadevan, ed. Plant Pathogenic Bacteria Centre for Advanced Study in Botany: University of Madras, Chennai, India.

Carbone, I., White, J. B., Miadlikowska, J., Arnold, A. E., Miller, M. A., Kauff, F., U'ren, J. M., May, G., and Lutzoni, F. 2016. T-BAS: Tree-Based Alignment Selector toolkit for phylogenetic-based placement, alignment downloads and metadata visualization: An example with the Pezizomycotina tree of life. Bioinformatics 33:1160-1168.

Conover, R. A., and Gerhold, N. R. 1981. Mixtures of copper and maneb or mancozeb for control of bacterial spot of tomato and their compatibility for control of fungus diseases. Proc. Fla. State Hortic. Soc. 94:154-156. 
Cooksey, D. A. 1987. Characterization of a copper resistance plasmid conserved in copper-resistant strains of Pseudomonas syringae pv. tomato. Appl. Environ. Microbiol. 53:454-456.

Cooksey, D. A., Azad, H. R., Cha, J. S., and Lim, C. K. 1990. Copper resistance gene homologs in pathogenic and saprophytic bacterial species from tomato. Appl. Environ. Microbiol. 56:431-435.

Cuppels, D. A., Louws, F. J., and Ainsworth, T. 2006. Development and evaluation of PCR based diagnostic assays for the bacterial speck and bacterial spot pathogens of tomato. Plant Dis. 90:451-458.

Davies, J. E. 1986. Aminoglycoside-aminocyclitol antibiotics and their modifying enzymes. Pages 790-809 in: Antibiotics in Laboratory Medicine. V. Lorian, ed. Williams, Baltimore, MD.

Diancourt, L., Passet, V., Nemec, A., Dijkshoorn, L., and Brisse, S. 2010. The population structure of Acinetobacter baumannii: Expanding multi-resistant clones from an ancestral susceptible genetic pool. PLoS One 5:e10034.

Gale, E. F., Cundliffe, E., Reynolds, P. E., Richmond, M. H., and Waring, M. J. 1972. Molecular Basis of Antibiotic Action. John Wiley and Sons, New York.

Hert, A. P., Marutani, M., Momol, M. T., Roberts, P. D., Olson, S. M., and Jones, J. B. 2009. Suppression of the bacterial spot pathogen Xanthomonas euvesicatoria on tomato leaves by an attenuated mutant of Xanthomonas perforans. Appl. Environ. Microbiol. 75:3323-3330.

Hert, A. P., Roberts, P. D., Momol, M. T., Minsavage, G. V., Tudor-Nelson, S. M., and Jones, J. B. 2005. Relative importance of bacteriocin-like genes in antagonism of Xanthomonas perforans tomato race 3 to Xanthomonas euvesicatoria tomato race 1 strains. Appl. Environ. Microbiol. 71: 3581-3588.

Horvath, D. M., Stall, R. E., Jones, J. B., Pauly, M. H., Vallad, G. E., Dahlbeck, D., Staskawicz, B. J., and Scott, J. W. 2012. Transgenic resistance confers effective field level control of bacterial spot disease in tomato. PLoS One 7:e42036

Jones, E., Oliphant, T., and Peterson, P. 2014. \{SciPy\}: Open Source Scientific Tools for $\{$ Python $\}$. https://www.scipy.org/

Jones, J., Pohroneznt, K. L., Stall, R., and Jones, J. P. 1986. Survival of Xanthomonas campestris pv. vesicatoria in Florida on tomato crop residue, weeds, seeds, and volunteer tomato plants. Phytopathology 76:430-434.

Jones, J. B., and Jones, J. P. 1985. The effect of bactericides, tank mixing time and spray schedule on bacterial leaf spot of tomato. Proc. Fla. State Hortic. Soc. 98:244-247.

Jones, J. B., Lacy, G. H., Bouzar, H., Stall, R. E., and Schaad, N. W. 2004. Reclassification of the Xanthomonads associated with bacterial spot disease of tomato and pepper. Syst. Appl. Microbiol. 27:755-762.

Jones, J. B., Stall, R. E., and Bouzar, H. 1998. Diversity among xanthomonads pathogenic on pepper and tomato. Annu. Rev. Phytopathol. 36:41-58.

Jones, J. B., Stall, R. E., Scott, J. W., Somodi, G. C., Bouzar, H., and Hodge, N. C. 1995. A third tomato race of Xanthomonas campestris pv. vesicatoria. Plant Dis. 79:395-398.

Kebede, M., Timilsina, S., Ayalew, A., Admassu, B., Potnis, N., Minsavage, G., Goss, E. M., Hong, J. C., Strayer, A., Paret, M., Jones, J. B., and Vallad, G. E. 2014. Molecular characterization of Xanthomonas strains responsible for bacterial spot of tomato in Ethiopia. Eur. J. Plant Pathol. 140:677-688.

Kemble, J. M., ed. 2019. Southeastern US Vegetable Crop Handbook. Meister Media Worldwide.

Klement, Z., and Goodman, R. N. 1967. The role of the living bacterial cell and induction time in the hypersensitive reaction of tobacco plants. Phytopathology 57:322-323.

Kuhar, T. P., Ramon Arancibia, R., Rideout, S. L., and Reiter, M. S. 2019. Southeastern U.S. 2019 Vegetable Crop Handbook. AREC-66NP (SPES106NP). Virginia Cooperative Extension, Virginia Tech, and Virginia State University. https://www.pubs.ext.vt.edu/AREC/AREC-66/AREC-66.html

Kumar, S., Stecher, G., and Tamura, K. 2016. MEGA7: Molecular evolutionary genetics analysis version 7.0 for bigger datasets. Mol. Biol. Evol. 33:1870-1874

Louws, F. J. 2018. Evaluation of biopesticides and biorationals on bacterial canker and bacterial spot disease levels in tomato fresh-market production in North Carolina. In: ISHS Acta Horticulturae 1207: V International Symposium on Tomato Diseases: Perspectives and Future Directions in Tomato Protection. Moriones, E., Fernández-Muñoz, R., and Beuzón, C. R., eds. Málaga, Spain.

Louws, F. J., and Cuppels, D. A. 2001. Molecular techniques. Pages 321-327 in: Laboratory Guide for Identification of Plant Pathogenic Bacteria, 3rd Ed. Schaad, N., Jones, J., and Chun, W., eds. American Phytopathological Society, St. Paul, MN

Louws, F. J., Fulbright, D. W., Stephens, C. T., and de Bruijn, F. J. 1995. Differentiation of genomic structure by rep-PCR fingerprinting to rapidly classify Xanthomonas campestris pv. vesicatoria. Phytopathology 85: 528-536.

Louws, F. J., Wilson, M., Campbell, H. L., Cuppels, D. A., Jones, J. B., Shoemaker, P. B., Sahin, F., and Miller, S. A. 2001. Field control of bacterial spot and bacterial speck of tomato using a plant activator. Plant Dis. $85: 481-488$
Ma, X., Ivey, M. L., and Miller, S. 2011. First report of Xanthomonas gardneri causing bacterial spot of tomato in Ohio and Michigan. Plant Dis. 95: 1584.

Marco, G. M., and Stall, R. E. 1983. Control of bacterial spot of pepper initiated by strains of Xanthomonas campestris pv. vesicatoria that differ in sensitivity to copper. Plant Dis. 67:779-781.

McGrath, M. T., and LaMarsh, K. A. 2014. Evaluation of biopesticides for managing foliar diseases in organically-produced tomato, 2013. Plant Dis. Manage. Rep. 8:V194.

Miller, S., Mera, J. R., Pantigoso, H. A., Rehm, N. R., and Vrisman, C. M. 2014. Evaluation of bactericides and a plant activator for the control of bacterial leaf spot of processing tomatoes. Plant Dis. Manage. Rep. 9: V055.

Minsavage, G., Balogh, B., Stall, R., and Jones, J. 2003. New tomato races of Xanthomonas campestris pv. vesicatoria associated with mutagenesis of tomato race 3 strains. Phytopathology 93:S62.

Minsavage, G. V., Canteros, B. I., and Stall, R. E. 1990. Plasmid-mediated resistance to streptomycin in Xanthomonas capestris pv. vesicatoria. Phytopathology 80:719-723.

Mixon, J. T. 2012.Prevalence of copper resistance among foliar bacterial pathogens of tomato in Tennessee. Master's thesis. University of Tennessee, Knoxville, TN.

Obradovic, A., Jones, J. B., Momol, M. T., Olson, S. M., Jackson, L. E., Balogh, B., Guven, K., and Iriarte, F. B. 2005. Integration of biological control agents and systemic acquired resistance inducers against bacterial spot on tomato. Plant Dis. 89:712-716.

Pitcher, D. G., Saunders, N. A., and Owen, R. 1989. Rapid extraction of bacterial genomic DNA with guanidium thiocyanate. Lett. Appl. Microbiol. $8: 151-156$

Potnis, N., Timilsina, S., Strayer, A., Shantharaj, D., Barak, J. D., Paret, M. L., Vallad, G. E., and Jones, J. B. 2015. Bacterial spot of tomato and pepper: Diverse Xanthomonas species with a wide variety of virulence factors posing a worldwide challenge. Mol. Plant Pathol. 16:907-920.

Rademaker, J. L., and de Bruijn, F. J. 1997. Characterization and classification of microbes by rep-PCR genomic fingerprinting and computer assisted pattern analysis. Pages 151-171 in: DNA Markers: Protocols, Applications and Overviews. G. Caetano-Anollels and P. M. Gresshoffeds, eds. John Wiley, New York.

Richard, D., Boyer, C., Lefeuvre, P., Canteros, B. I., Beni-Madhu, S., Portier, P., and Pruvost, O. 2017. Complete genome sequences of six copperresistant Xanthomonas strains causing bacterial spot of Solanaceous plants, belonging to $X$. gardneri, $X$. euvesicatoria, and $X$. vesicatoria, using longread technology. Genome Announc. 5:e01693-e16.

Ritchie, D., and Dittapongpitch, V. 1991. Copper-and streptomycin-resistant strains and host differentiated races of Xanthomonas campestris pv. vesicatoria in North Carolina. Plant Dis. 75:733-736.

Sahin, F., and Miller, S. A. 1998. Resistance in Capsicum pubescens to Xanthomonas campestris pv. vesicatoria pepper race 6. Plant Dis. 82: 794-799.

Saraçli, S., Doğan, N., and Doğan, İ. 2013. Comparison of hierarchical cluster analysis methods by cophenetic correlation. J. Inequal. Appl. 2013:203.

Schwartz, A. R., Potnis, N., Timilsina, S., Wilson, M., Patané, J., Martins, J., Jr., Minsavage, G. V., Dahlbeck, D., Akhunova, A., Almeida, N., Vallad, G. E., Barak, J. D., White, F. F., Miller, S. A., Ritchie, D., Goss, E., Bart, R. S., Setubal, J. C., Jones, J. B., and Staskawicz, B. J. 2015. Phylogenomics of Xanthomonas field strains infecting pepper and tomato reveals diversity in effector repertoires and identifies determinants of host specificity. Front. Microbiol. 6:535.

Scott, J. W., Stall, R. E., Jones, J. B., and Somodi, G. C. 1996. A single gene controls the hypersensitive response of Hawaii7981 to race 3 (T3) of the bacterial spot pathogen. Rpt. Tomato Genet Coop. 46:23.

Sharlach, M., Dahlbeck, D., Liu, L., Chiu, J., Jiménez-Gómez, J. M., Kimura, S., Koenig, D., Maloof, J. N., Sinha, N., Minsavage, G. V., and Jones, J. B. 2013. Fine genetic mapping of RXopJ4, a bacterial spot disease resistance locus from Solanum pennellii LA716. Theor. Appl. Genet. 126:601-609.

Shenge, K. C., Mabagala, R. B., Mortensen, C. N., and Wydra, K. 2014. Resistance of Xanthomonas campestris pv. vesicatoria isolates from Tanzania to copper and implications for bacterial spot management. Afr. J. Microbiol. Res. 8:2881-2885.

Springer, B., Kidan, Y. G., Prammananan, T., Ellrott, K., Böttger, E. C., and Sander, P. 2001. Mechanisms of streptomycin resistance: Selection of mutations in the $16 \mathrm{~S}$ rRNA gene conferring resistance. Antimicrob. Agents Chemother. 45:2877-2884.

Stall, R. E., Jones, J. B., and Minsavage, G. V. 2009. Durability of resistance in tomato and pepper to Xanthomonads causing bacterial spot. Annu. Rev. Phytopathol. 47:265-284.

Stall, R. E., Loschke, D. C., and Jones, J. B. 1986. Linkage of copper resistance and avirulence loci on a self-transmissible plasmid in Xanthomonas campestris pv. vesicatoria. Mol. Plant Pathol. 76:240-243. 
Stall, R. E., and Thayer, P. L. 1962. Streptomycin resistance of the bacterial spot pathogen and control with streptomycin. Plant Dis. Rep. 46:389-392.

Strayer, A. L., Jeyaprakash, A., Minsavage, G. V., Timilsina, S., Vallad, G. E., Jones, J. B., and Paret, M. L. 2016. A multiplex real-time PCR assay differentiates four Xanthomonas species associated with bacterial spot of tomato. Plant Dis. 100:1660-1668.

Strayer-Scherer, A., Liao, Y. Y., Young, M., Ritchie, L., Vallad, G. E., Santra, S., Freeman, J. H., Clark, D., Jones, J. B., and Paret, M. L. 2018. Advanced copper composites against copper-tolerant Xanthomonas perforans and tomato bacterial spot. Phytopathology 108:196-205.

Thayer, P. L., and Stall, R. E. 1962. Effect of variation in the bacterial spot pathogen of pepper and tomato on control with streptomycin. Phytopathology 51:568-571.

Timilsina, S., Abrahamian, P., Potnis, N., Minsavage, G. V., White, F. F., Staskawicz, B. J., Jones, J. B., Vallad, G. E., and Goss, E. M. 2016. Analysis of sequenced genomes of Xanthomonas perforans identifies candidate targets for resistance breeding in tomato. Phytopathology 106:1097-1104.

Timilsina, S., Jibrin, M. O., Potnis, N., Minsavage, G. V., Kebede, M., Schwartz, A., Bart, R., Staskawicz, B., Boyer, C., Vallad, G. E., Pruvost, O.,
Jones, J. B., and Goss, E. M. 2015. Multilocus sequence analysis of Xanthomonads causing bacterial spot of tomato and pepper plants reveals strains generated by recombination among species and recent global spread of Xanthomonas gardneri. Appl. Environ. Microbiol. 81:1520-1529.

Tudor-Nelson, S. M., Minsavage, G. V., Stall, R. E., and Jones, J. B. 2003. Bacteriocin-Like substances from tomato race 3 strains of Xanthomonas campestris pv. vesicatoria. Phytopathology 93:1415-1421.

Vallad, G. E., and Goodman, R. M. 2004. Systemic acquired resistance and induced systemic resistance in conventional agriculture. Crop Sci. 44: 1920-1934.

Vallad, G. E., Timilsina, S., Adkison, H., Potnis, N., Minsavage, G., Jones, J., and Goss, E. 2013. A recent survey of Xanthomonads causing bacterial spot of tomato in Florida provides insights into management strategies. 2013 Florida Tomato Institute, Naples, FL.

Whalen, M. C., Wang, J. F., Carland, F. M., Heiskell, M. E., Dahlbeck, D., Minsavage, G. V., Jones, J. B., Scott, J. W., Stall, R. E., and Staskawicz, B. J. 1993. Avirulence gene avrRxv from Xanthomonas campestris pv. vesicatoria specifies resistance on tomato line HI 7998. Mol. Plant-Microbe Interact. 6:616-627. 